\title{
Quantification of Organochlorine Pesticide Residues in the Buffalo Milk Samples of Delhi City, India
}

\author{
Mohd Aslam ${ }^{1,2}$, Sumbul Rais ${ }^{2 *}$, Masood Alam ${ }^{2}$ \\ ${ }^{1}$ Center of Excellence in Environmental Studies, King Abdulaziz University, Jeddah, KSA; ${ }^{2}$ Department of Applied Sciences and \\ Humanities, Faculty of Engineering and Technology, Jamia Millia Islamia, New Delhi, India. \\ Email:*sumbulrais@gmail.com
}

Received June $11^{\text {th }}, 2013$; revised July $15^{\text {th }}, 2013$; accepted August $13^{\text {th }}, 2013$

Copyright (C) 2013 Mohd Aslam et al. This is an open access article distributed under the Creative Commons Attribution License, which permits unrestricted use, distribution, and reproduction in any medium, provided the original work is properly cited.

\begin{abstract}
The ill effects of green revolution include residues of extensively used chemical pesticides in various environmental components. The present study was designed to analyze the levels of organochlorine pesticide residues along with chemical composition in buffalo milk samples collected from different localities of Delhi. Milk monitoring can yield information about the kinds and quantities of pesticides in the environment as well as in our daily diet. In this study, the residue of three different organochlorine pesticides, namely Hexachlorocyclohexane $(\mathrm{HCH})$, Dichlorodiphenyltrichloroethane (DDT) and Endosulfan have been reported. Residues of Lindane exceeded the Maximum Residual Limit values in $50 \%$ of the samples is a cause of serious concern. The p,p'-DDT was detected in $70 \%$ of the samples with p,p'-DDE (dichlorodiphenyldichloroethylene) in $80 \%$ of the milk samples of different parts of Delhi state. DDD (Dichlorodiphenyldichloroethane) another metabolite of p,p'-DDT was detected in $65 \%$ of the milk samples. The analysis indicates that DDT is the major contaminants in different parts of Delhi state. $\alpha$ and $\beta$ endosulfan were detected in $35 \%$ and $40 \%$ of the samples analyzed. The statistical correlation shows no significant correlation between chemical compositions of the samples. The presence of multiple chemicals in virtually all samples of buffalo milk raises new questions about the possible toxicological impacts of chemical mixtures on an infant's developing nervous and immune systems and reproductive organs.
\end{abstract}

Keywords: Organochlorine Pesticides; Residues; Buffalo Milk; Delhi

\section{Introduction}

The milk and its products, which are nutritionally enriched, with superior biological potential and the one without health risks, are usually demanded [1-3] which include neurodevelopmental delay [4], reproductive effects [5], preterm \& small-for-gestational-age babies [6] and immunotoxicity [7]. The presence of any chemical in milk is a cause for concern and great strides are taken throughout the dairy industry to assure the purity of the milk. The presence of multiple chemicals in virtually all samples of milk raises new questions about the possible toxicological impacts of chemical mixtures on an infant's developing nervous and immune systems and reproductive organs. During key stages of development, these parts of the body are known to be very sensitive to the exposures of chemicals, including pesticides. Milk is nearly a perfect natural food widely used in all segments

${ }^{*}$ Corresponding author. of the population in all stages of life [8,9]. Milk is considered as a nearly complete food as it contains a good source of protein, fat and major minerals [10] which serves as a source of energy. For the marketing in many developed countries such as the US and Switzerland, milk is highly used by cosmetics industry in manufacturing several skin whitening soaps, body lotions, shampoos, hair conditioners creams and after shave lotions [11].

Being one of the highest levels of the trophic chain and due to its lipophilic nature $[12,13]$, milk has been usually studied as an indicator of the bioconcentration process of environmentally persistent organic micropollutants, such as organochlorinated (OC) pesticides [14]. Organochlorine pesticides were extensively used to increase the production of agricultural crops by preventing losses due to pest [15]. Worldwide production and use of Organochlorine compounds (OCs) since 1950s have resulted in their widespread occurrence in the environment. They have also been used to control various factors, 
which spread diseases like malaria or plague $[16,17]$. Serious health problems such as heart diseases, cancers, damage the nervous system, reproductive and endocrinal damages, Alzheimer's and Parkinsonism disease may be the consequences of pesticides in food. As pesticides persist in the environment for a long time and as a consequence, they enter the human body through the food chain $[8,18,19]$. Poisoning cases in human beings are characterized by headache, dizziness, gastrointestinal disturbances, numbness, apprehension and hyperirritability and weakness of the extremities. Adverse health effects are not expected from consuming water with pesticides below the maximum residue limits. Maximum residue limits for parent $\mathrm{OC}$ pesticides have been set by several organizations such as FAOCodex Alimentarius [20] and European Union [21].

The cow, milker, extraneous dirt, environment or unclean water may be the reason of milk contamination [22]. The possible number of ways in which pesticides can reach milk are as follows: 1) high level of pesticide residues in foodstuffs from post-harvest treatment or by drift during commercial aerial application, inhaled air or contaminated water, 2) foodstuffs manufactured from plant material that has been treated during the growing season with insecticides i.e. contamination through feed, grass/hay [23], 3) use of insecticides directly on the animals against disease vectors, 4) use of insecticides in stables for the treatment against flies, 5) in milk processing factories for hygienic treatments against insects. The contamination of milk from source 1) and 2) with pesticide depends on the stability of the compound, its mode of application, the duration of intake or exposure and its metabolic fate in the animal. Due to their lipophilic properties [13], pesticides are primarily stored in fat-rich tissues and subsequently translocated and excreted through milk fat $[24,25]$.

Studies have been carried out on pesticidal contamination of food stuff from different parts of the world [2632]. Limited information is available from India on the nature of pesticide residues in milk. Milk samples from various parts of India contained DDT (Dichlorodiphenyltrichloroethane) and $\mathrm{HCH}$ (Hexachlorocyclohexane) residues [7,33-37]. The Organochlorine Pesticide (OCP) residues in buffalo and goat milk from Lucknow have been reporte [38]. Kathpal et al., (1992) and Kumar and Nath (1996) have reported residues of DDT in milk collected from Haryana and Himachal Pradesh, respectively [39, 40]. Human milk has also been reported to be contaminated by various pesticides in a range of $0.1 \mathrm{mg} \cdot \mathrm{l}^{-1}-25.7$ $\mathrm{mg} \cdot \mathrm{l}^{-1}$ concentrations [41].

The presence of residues of persistent organochlorine pesticides in various components of the environment is a matter of great concern all over the world. The purpose of the present study was to determine the concentration of DDT (Dichlorodiphenyltrichloroethane), HCH (Hexachlorocyclohexane) and endosulphan residues in buffalo milk samples collected from different locations of Delhi, India. The structures of the DDT and $\mathrm{HCH}$ are mentioned below.

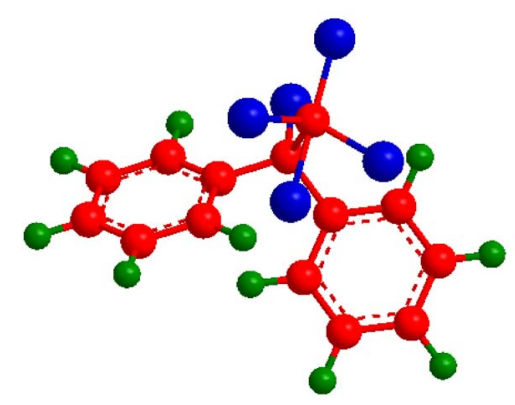

Dichlorodiphenyltrichloroethane $\left(\mathrm{C}_{14} \mathrm{H}_{9} \mathrm{Cl}_{5}\right)$

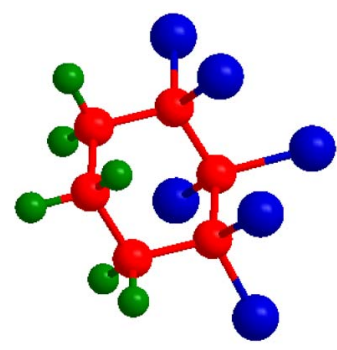

Hexachlorocyclohexane $\left(\mathrm{C}_{6} \mathrm{H}_{6} \mathrm{Cl}_{6}\right)$

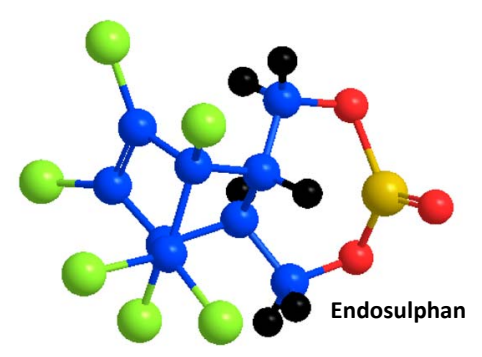

\section{Materials and Methods}

\subsection{Milk Samples}

Twenty fresh buffalo's milk samples were collected from several farms located in different districts of Delhi, viz., south (S), south west (SW), west (W), north (N), north east (NE), north west (NW), east (E) and central delhi (CD), in clean and sterlized glass bottles (Figure 1). The sampling was carried out during the period of January 2012 to September 2012. The milk samples were kept on ice immediately after collection, transferred to the environmental science laboratory at Jamia Millia Islamia and preserved at $-20^{\circ} \mathrm{C}$ until analyzed.

\subsection{Chemicals and Pesticide Standards}

All the chemicals used in the study were of analytical 


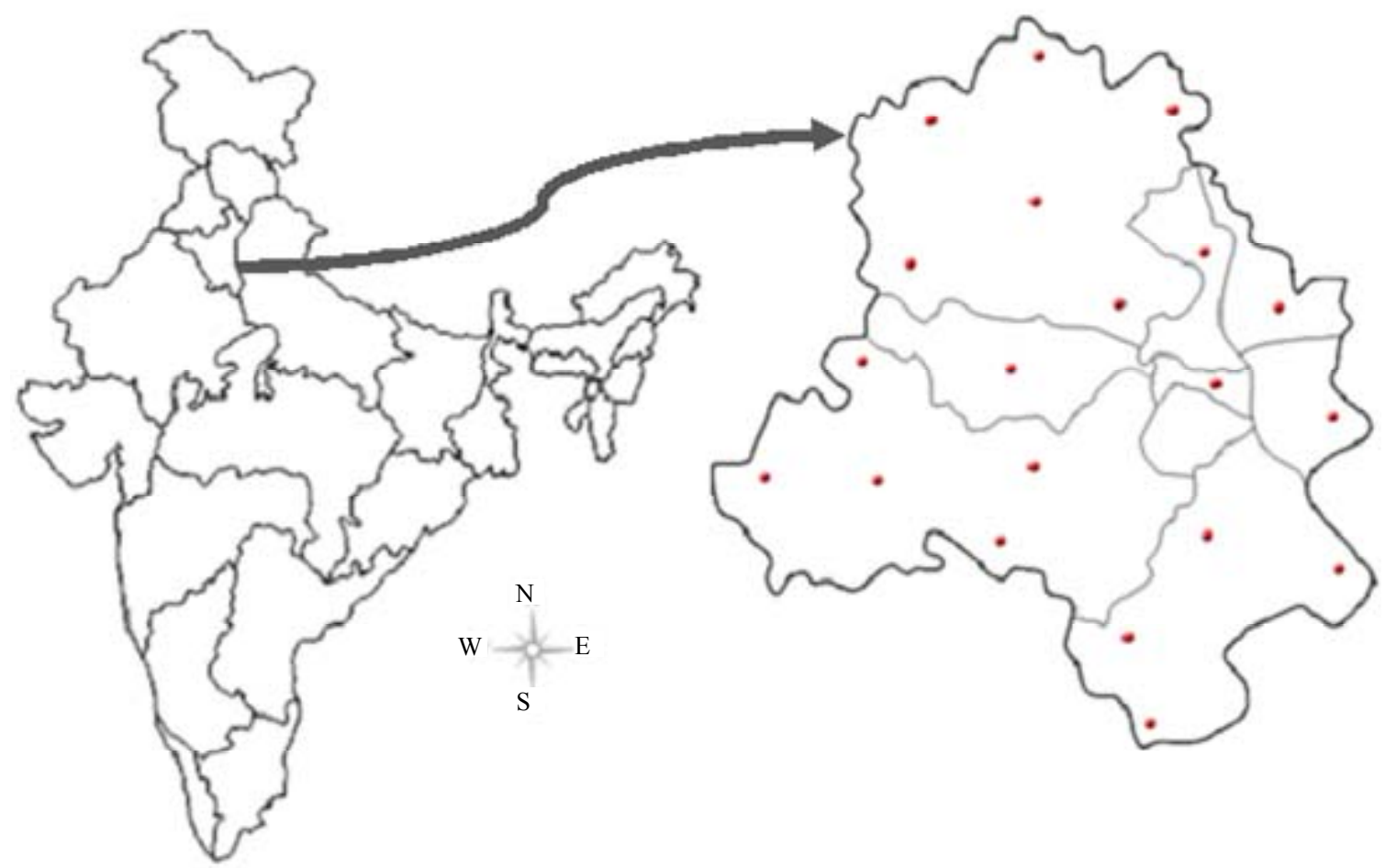

Figure 1. Map of the study area showing the different sampling locations.

reagent (AR) grade. Dichloromethane, hexane, and acetone used were all pesticide grades, while silica gel, sodium chloride, and anhydrous sodium sulfate were all analytical grades. These chemicals were purchased from Sigma Aldrich. Organochlorine Pesticide (OCP) standards of Dichlorodiphenyltrichloroethane (DDT), Hexachlorocyclohexane $(\mathrm{HCH})$ and Endosulfan were purchased from Accustandards.

\subsection{Methods of Analysis}

\subsubsection{Chemical Analysis}

The physicochemical parameters, viz., $\mathrm{pH}$, total solid (T.S \%), fat (\%) and ash (\%), for all the collected milk samples from different locations of delhi, were analyzed according to the AOAC (1995) [42]. The $\mathrm{pH}$ of the milk samples were analyzed with potentiometric method, total solids and ash were analyzed by gravimtric method and fat content by Gerber method with the help of butyrometer.

\subsubsection{Extraction}

As the occurrence of pesticide residues in milk has been extensively studied, vast choice of methodologies is available for the determination of pesticide residues. Milk falls into the category of fatty foods, the analysis of OC as well as OP pesticide residues follows the conventional approach of the multi-matrix, multiresidue methods in which the total residues are extracted together with the total" fatty material [43-47].

For milk, the bulk of fat together with lipophilic pesticide residues can be obtained by extraction using light petroleum-diethyl ether $(1: 1, \mathrm{v} / \mathrm{v})$, potassium oxalate and ethanol [43] (Helrich, 1990), n-hexane-acetone (1:1, v/v) [11], or acetone extraction followed by a partition into dichloromethane [46]. Liquid-Liquid Extraction with $\mathrm{n}$-hexane-acetone $(1: 1, \mathrm{v} / \mathrm{v})$ was used. Milk sample (15 $\mathrm{ml}$ ) was transferred to a clean glass-stoppered cylinder and $80 \mathrm{ml}$ of acetone: $\mathrm{n}$-hexane $(1: 1, \mathrm{v} / \mathrm{v})$ was added to it and shaken vigorously. The homogenate was allowed to stand until a clear separation of two layers had occurred. After the removal of the upper organic phase, the lower phase was re-extracted twice with $30 \mathrm{ml}$-hexane. The precipitate was centrifuged at $4000 \mathrm{rpm}$ and the remaining solvent was also combined. The concentrated nhexane extract was taken in a $100 \mathrm{ml}$ separating funnel and $35 \mathrm{ml}$ concentrated sulphuric acid (sp. Gravity 1.84) was added to it drop wise. The mixture was allowed to stand until a clear separation of two layers. The upper clear phase was collected and lower phase of spent sulphuric acid was discarded. The collected upper phase was then washed with the distilled water. The collected extract was evaporated to dryness using a rotary evaporator and concentrated to about $5 \mathrm{ml}$ with $\mathrm{n}$-hexane. The final extracts were transferred to autosampler vials for $\mathrm{GC}$ analysis. The flow diagram of extraction process of buffalo milk samples for multiresidue analysis of pesticides is shown in Figure 2. 


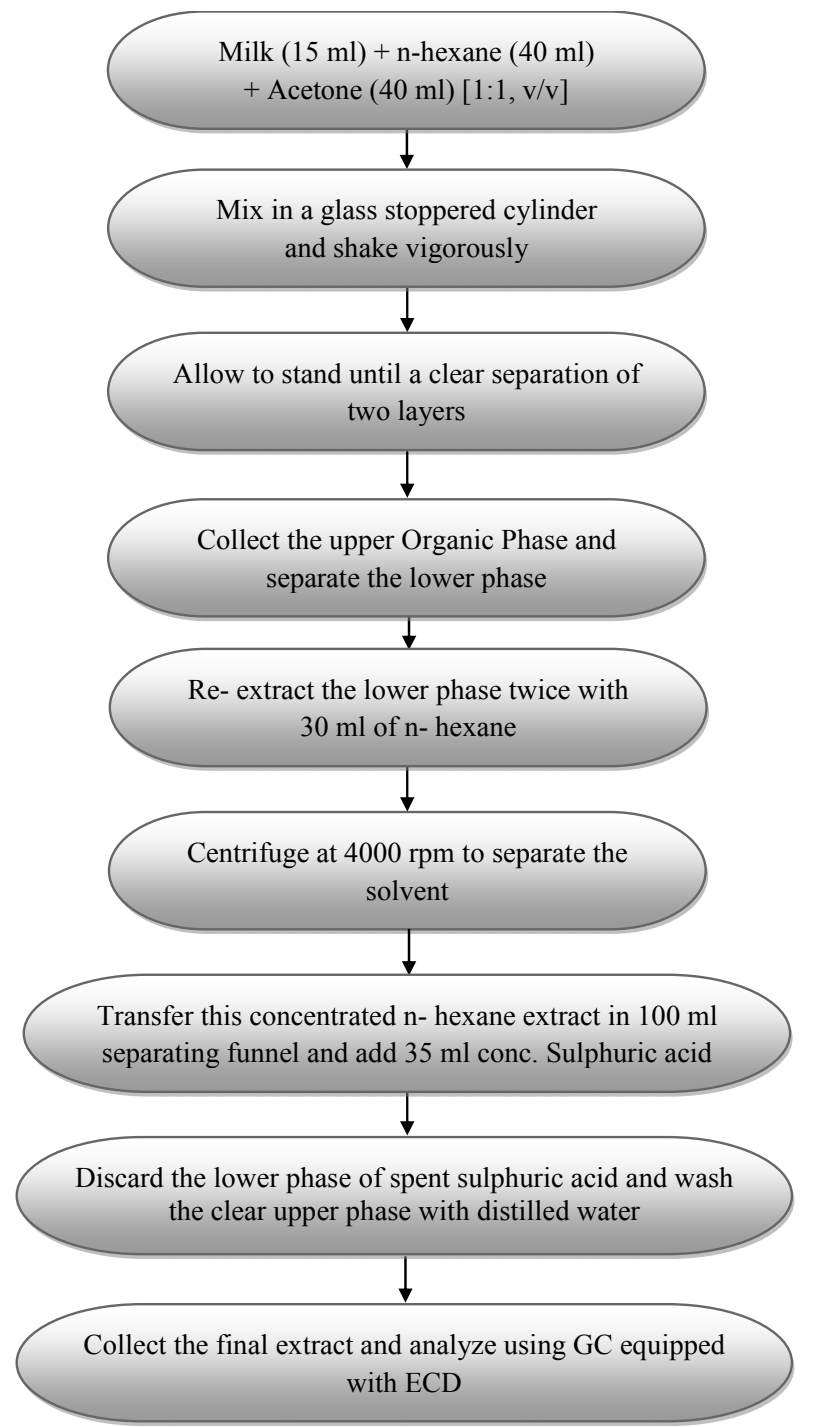

Figure. 2. Flow diagram of extraction of liquid Buffalo milk samples for multiresidue analysis of pesticides.

Recoveries were determined by spiking of milk with pesticides solution of known concentration. The average recoveries of fortified samples were exceeding $95 \%$.

\subsection{Statistical Analysis}

All the data on the pesticide concentrations in milk samples were subjected to analysis of variance using SPSS 9.0 software. A correlation between the physicochemical parameters of milk samples and the experimentally determined pesticides residues, were calculated on Microsoft Excel version 2007.

\subsection{Pesticide Residues Analysis}

The separation and detection of analyzing pesticides were performed by high resolution Gas Chromatography. Gas chromatography (GC) analysis was performed using an Agilent 7890A Gas Chromatograph equipped with ${ }^{63} \mathrm{Ni}$ electron capture detector (ECD). The GC system was equipped with DB-5 (30 m length $\times 0.25 \mathrm{~mm}$ diameter $\times 0.25 \mu \mathrm{m}$ film thickness) capillary column. Hydrogen (99.9\% purity) was used as the carrier gas, while nitrogen was used as an auxiliary gas for the ECD. The separation was operated under the following conditions: Oven temperature program: $100^{\circ} \mathrm{C}$ for $2 \mathrm{~min}, 15^{\circ} \mathrm{C} / \mathrm{min}$ to $160^{\circ} \mathrm{C}, 5^{\circ} \mathrm{C} / \mathrm{min}$ to $270^{\circ} \mathrm{C}$; Nitrogen flow rate $2 \mathrm{ml} / \mathrm{min}$; Injector mode splitless and temperature: $225^{\circ} \mathrm{C}$; injection volume: $1 \mu \mathrm{l}$; Detector temperature $300^{\circ} \mathrm{C}$. Quantitative and qualitative analysis were done by comparison with external standard. To determine the quality of the method, the recovery study was performed.

\section{Results and Discussion}

\subsection{Chemical Composition}

Table 1 describes the determined chemical composition of buffalo's milk samples. The $\mathrm{pH}$ range of the milk

Table 1. Chemical composition in the milk samples collected from different regions of Delhi, India.

\begin{tabular}{|c|c|c|c|c|c|c|}
\hline S.No. & Sample ID & District & pH & Fat $\%$ & T.S \% & Ash \% \\
\hline 1 & S-1 & South & 6.42 & 5.9 & 13.61 & 0.69 \\
\hline 2 & S-2 & South & 6.21 & 5.7 & 13.24 & 0.62 \\
\hline 3 & S-3 & South & 6.55 & 5.8 & 12.8 & 0.84 \\
\hline 4 & SW-1 & South West & 6.51 & 5.6 & 13.9 & 0.61 \\
\hline 5 & SW-2 & South West & 6.71 & 5.7 & 14.2 & 0.74 \\
\hline 6 & SW-3 & South West & 6 & 7.3 & 13.48 & 0.81 \\
\hline 7 & W-1 & West & 6.49 & 5.9 & 13.19 & 0.77 \\
\hline 8 & $\mathrm{~W}-2$ & West & 6.32 & 5.7 & 12.95 & 0.76 \\
\hline 9 & W-3 & West & 6.56 & 6.1 & 13.61 & 0.69 \\
\hline 10 & E-1 & East & 6.65 & 6.2 & 11.13 & 0.8 \\
\hline 11 & E-2 & East & 6.47 & 6.7 & 12.87 & 0.83 \\
\hline 12 & $\mathrm{~N}-1$ & North & 6.58 & 7 & 12.91 & 0.92 \\
\hline 13 & $\mathrm{~N}-2$ & North & 6.12 & 7.3 & 13.65 & 0.86 \\
\hline 14 & NE-1 & North East & 6 & 8.5 & 13.87 & 0.71 \\
\hline 15 & NE-2 & North East & 6.37 & 7.1 & 13.18 & 0.92 \\
\hline 16 & CD-1 & Central Delhi & 6.51 & 6 & 13.76 & 0.64 \\
\hline 17 & CD-2 & Central Delhi & 6.37 & 5.9 & 13.19 & 0.66 \\
\hline 18 & NW-1 & North West & 6.28 & 6.1 & 11.40 & 0.85 \\
\hline 19 & NW-2 & North West & 6.71 & 5.8 & 13.48 & 0.69 \\
\hline \multirow[t]{5}{*}{20} & NW-3 & North West & 6.43 & 7.6 & 13.71 & 0.62 \\
\hline & Average & & 6.413 & 6.395 & 13.206 & 0.7515 \\
\hline & Maximum & & 6.71 & 8.5 & 14.2 & 0.92 \\
\hline & Minimum & & 6 & 5.6 & 11.13 & 0.61 \\
\hline & Mean & & 6.413 & 6.395 & 13.2065 & 0.7515 \\
\hline
\end{tabular}


samples varied from 6 to 6.7 with the mean value of 6.413. The fat value was observed between $5.6 \%$ and $8.5 \%$ with mean value of $6.395 \%$. This difference in percent fat content may be due to the difference in feeding, management practices, season and breed of the animals [48]. The mean value of fat content is $6.395 \%$ which is lower than the standard content of 7.45\% [49]. Total solids are one of the parameters used for the quality of milk [50]. The concentration range of total solids is from $14.2 \%$ to $11.13 \%$ with the mean value of $13.20 \%$ as shown in Figure 3. These results showed that the amount of total solids recorded is low in the range as recorded in the literature [49]. The overall mean ash content of milk is reported as $0.75 \%$. The amount of ash content in milk should be closer to $0.78 \%$ [49] and similar readings are also reported [50]. The statistical analysis presented in the Table 2, showed that the $\mathrm{pH}$, fat, total solids, ash content, $\sum$-DDT, $\sum$-HCH and $\sum$-Endosulfan of all the samples were significantly different from each other. The $\mathrm{pH}$ and Endosulfan shows negative co-relation with all other parameter. Only endosulfan shows some good relation with Fat $\%$ and rest all show slight co-relations, but to a negligible extend.

\subsection{Pesticide Residue}

The frequency distribution of organochlorine pesticide residues detected in the analyzed buffalo milk samples are shown in Table 3-5. Hexachlorocyclohexane (HCH) is used against sucking and biting pests and as smoke for control of pests in grain stores. It is used as dust to control various soil pests such as flea beetles and mushroom flies. It is also present in the list of banned pesticides in India (with effect from April 1, 1997). Hexachlorocyclohexane, previously called BHC (benzene hexachloride), is a mixture of eight isomers out of which five are found in the crude product $(\alpha, \beta, \gamma, \delta, \varepsilon)$. Only the $\gamma$-isomer or lindane has powerful insecticidal properties. The presence of $\gamma-\mathrm{HCH}$ (Lindane) detected in $100 \%$ of the analyzed milk samples in the range of 0.0001 to
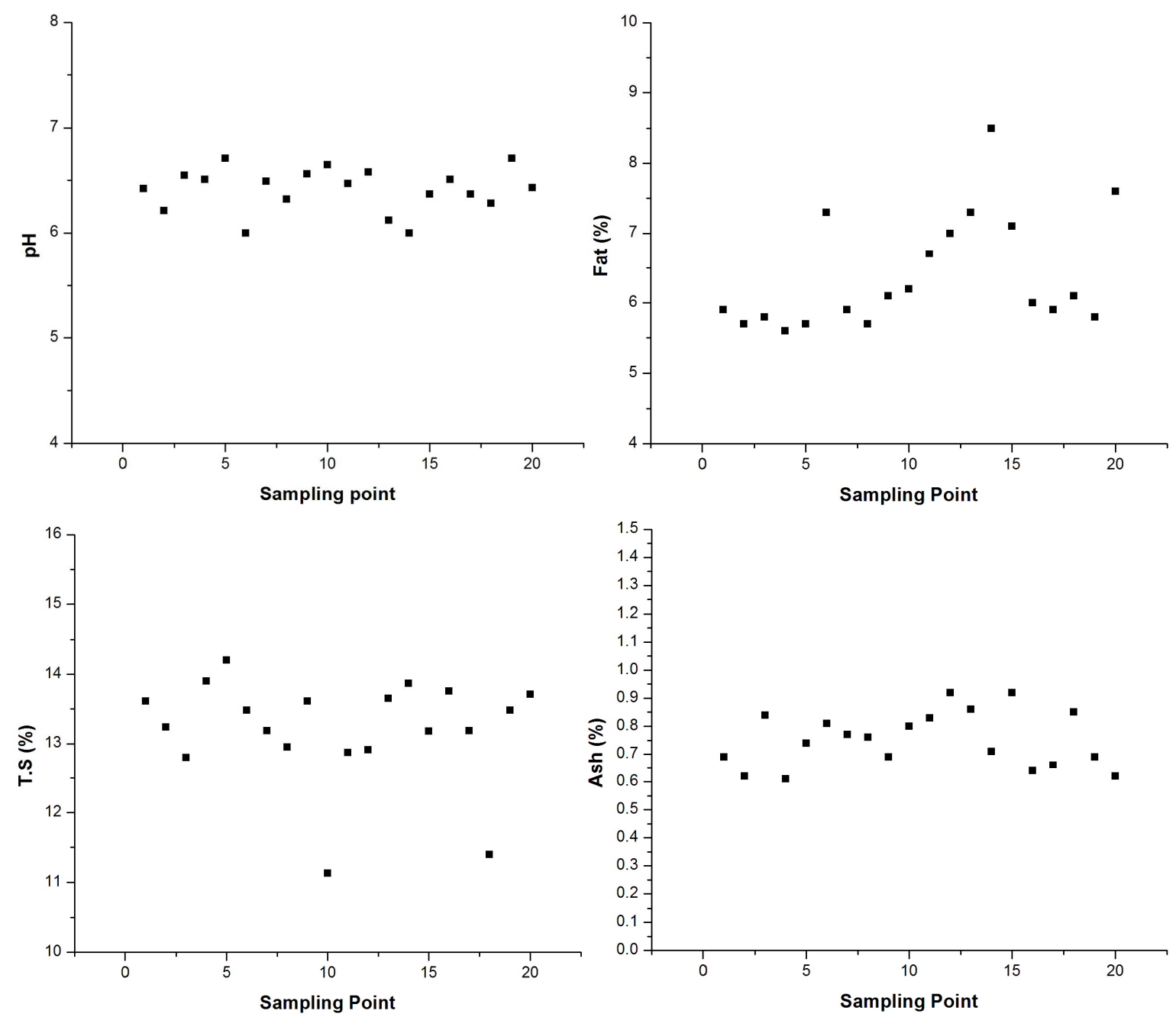

Figure 3. Chemical composition of Buffalo's milk samples collected from different districts of Delhi. 
Table 2. Statistical correlation between chemical composition of milk samples.

\begin{tabular}{|c|c|c|c|c|c|c|c|}
\hline & $\mathbf{p H}$ & Fat $\%$ & T.S\% & Ash\% & $\Sigma-H C H$ & $\Sigma$-DDT & $\Sigma$-Endo \\
\hline $\mathrm{pH}$ & 1 & -0.577 & -0.172 & -0.075 & -0.37014 & -0.51187 & -0.05254 \\
\hline Fat $\%$ & & 1 & 0.2528 & 0.2828 & 0.886488 & 0.442419 & -0.16151 \\
\hline T.S\% & & & 1 & -0.618 & 0.075122 & 0.040057 & -0.22823 \\
\hline Ash $\%$ & & & & 1 & 0.359993 & 0.241355 & -0.10587 \\
\hline$\Sigma-\mathrm{HCH}$ & & & & & 1 & 0.156254 & -0.05517 \\
\hline$\Sigma$-DDT & & & & & & 1 & -0.098 \\
\hline$\Sigma$-Endo & & & & & & & 1 \\
\hline
\end{tabular}

Table 3. Quantitative determination of $\Sigma-\mathrm{HCH}$ in the milk samples collected from different regions of Delhi, India.

\begin{tabular}{|c|c|c|c|c|c|c|c|}
\hline S.No. & Sample ID & District & $\alpha-\mathrm{HCH}$ & $\beta$-НCH & $\gamma-\mathrm{HCH}$ & $\delta$-HCH & $\Sigma-H C H$ \\
\hline 1 & S-1 & South & 0.002 & 0 & 0.001 & 0 & 0.003 \\
\hline 2 & S-2 & South & 0 & 0.014 & 0.018 & 0 & 0.032 \\
\hline 3 & $\mathrm{~S}-3$ & South & 0.008 & 0 & 0.002 & 0 & 0.01 \\
\hline 4 & SW-1 & South West & 0.007 & 0 & 0.003 & 0 & 0.01 \\
\hline 5 & SW-2 & South West & 0.141 & 0 & 0.001 & 0 & 0.142 \\
\hline 6 & SW-3 & South West & 0.212 & 0 & 0.12 & 0 & 0.332 \\
\hline 7 & W-1 & West & 0.001 & 0 & 0.013 & 0 & 0.014 \\
\hline 8 & $\mathrm{~W}-2$ & West & 0.08 & 0.013 & 0.01 & 0 & 0.103 \\
\hline 9 & W-3 & West & 0.018 & 0 & 0.009 & 0 & 0.027 \\
\hline 10 & E-1 & East & 0 & 0.355 & 0.014 & 0 & 0.369 \\
\hline 11 & E-2 & East & 0.017 & 0.982 & 0.002 & 0 & 1.001 \\
\hline 12 & $\mathrm{~N}-1$ & North & 0.002 & 0.511 & 0.11 & 0 & 0.623 \\
\hline 13 & $\mathrm{~N}-2$ & North & 0.03 & 0 & 0.856 & 0 & 0.886 \\
\hline 14 & NE-1 & North East & 0.182 & 0 & 0.94 & 0 & 1.122 \\
\hline 15 & NE-2 & North East & 0 & 0.86 & 0.06 & 0 & 0.92 \\
\hline 16 & CD-1 & Central Delhi & 0.023 & 0.005 & 0.036 & 0 & 0.064 \\
\hline 17 & CD-2 & Central Delhi & 0.022 & 0 & 0.0001 & 0 & 0.0221 \\
\hline 18 & NW-1 & North West & 0.205 & 0 & 0.001 & 0 & 0.206 \\
\hline 19 & NW-2 & North West & 0 & 0.012 & 0.004 & 0 & 0.016 \\
\hline \multirow[t]{5}{*}{20} & NW-3 & North West & 0.01 & 0 & 1.081 & 0 & 1.091 \\
\hline & Average & & 0.048 & 0.1376 & 0.1640 & 0 & 0.34965 \\
\hline & Maximum & & 0.212 & 0.982 & 1.081 & 0 & 1.122 \\
\hline & Minimum & & 0 & 0 & 0.0001 & 0 & 0.003 \\
\hline & Mean & & 0.048 & 0.1376 & 0.164055 & 0 & 0.349655 \\
\hline
\end{tabular}

$\boldsymbol{\alpha}$-HCH: alpha-Hexachlorocyclohexane; $\boldsymbol{\beta}$-HCH: beta-Hexachlorocyclohexane; $\boldsymbol{\gamma}$-HCH: gamma-Hexachlorocyclohexane; $\boldsymbol{\delta}$-HCH: delta-Hexachlorocyclohexane; $\boldsymbol{\Sigma}$-HCH: Sum of Hexachlorocyclohexane. 
Table 4. Quantitative determination of $\Sigma$-DDT in the milk samples collected from different regions of Delhi, India.

\begin{tabular}{|c|c|c|c|c|c|c|c|}
\hline S.No. & Sample ID & District & p,p'-DDE & p,p'-DDD & o,p'-DDT & p,p'-DDT & $\Sigma$-DDT \\
\hline 1 & S-1 & South & 0.097 & 0.009 & 0 & 0 & 0.106 \\
\hline 2 & S-2 & South & 0.083 & 0.005 & 0 & 0.003 & 0.091 \\
\hline 3 & S-3 & South & 0.002 & 0.086 & 0 & 0 & 0.088 \\
\hline 4 & SW-1 & South West & 0.073 & 0.003 & 0 & 0.094 & 0.17 \\
\hline 5 & SW-2 & South West & 0.005 & 0.012 & 0.018 & 0.051 & 0.086 \\
\hline 6 & SW-3 & South West & 0.97 & 0.046 & 0 & 0 & 1.016 \\
\hline 7 & W-1 & West & 0 & 0 & 0.017 & 0.085 & 0.102 \\
\hline 8 & W-2 & West & 0.064 & 0.001 & 0.0004 & 0.13 & 0.1954 \\
\hline 9 & W-3 & West & 0 & 0 & 0 & 0 & 0 \\
\hline 10 & E-1 & East & 0.024 & 0 & 0 & 0.078 & 0.102 \\
\hline 11 & E-2 & East & 0.068 & 0.002 & 0.023 & 0.01 & 0.103 \\
\hline 12 & $\mathrm{~N}-1$ & North & 0.31 & 0.038 & 0 & 0.063 & 0.411 \\
\hline 13 & $\mathrm{~N}-2$ & North & 0.006 & 0.001 & 0.006 & 0.006 & 0.019 \\
\hline 14 & NE-1 & North East & 0.242 & 0.094 & 0 & 0.095 & 0.431 \\
\hline 15 & NE-2 & North East & 0.027 & 0.003 & 0 & 0.093 & 0.123 \\
\hline 16 & CD-1 & Central Delhi & 0.002 & 0.001 & 0 & 0 & 0.003 \\
\hline 17 & $\mathrm{CD}-2$ & Central Delhi & 0.001 & 0.001 & 0.001 & 0.055 & 0.058 \\
\hline 18 & NW-1 & North West & 0 & 0 & 0 & 0 & 0 \\
\hline 19 & NW-2 & North West & 0.018 & 0.011 & 0 & 0.002 & 0.031 \\
\hline \multirow[t]{5}{*}{20} & NW-3 & North West & 0 & 0 & 0 & 0 & 0 \\
\hline & Average & & 0.0996 & 0.01565 & 0.00327 & 0.03825 & 0.15677 \\
\hline & Maximum & & 0.97 & 0.094 & 0.023 & 0.13 & 1.016 \\
\hline & Minimum & & 0 & 0 & 0 & 0 & 0 \\
\hline & Mean & & 0.0996 & 0.01565 & 0.00327 & 0.03825 & 0.15677 \\
\hline
\end{tabular}

p,p'-DDE: para, para- Dichlorodiphenyldichloroethylene; p,p'-DDD: para, para- Dichlorodiphenyldichloroethane; o,p'-DDT: ortho, para- dichlorodiphenyltrichloroethane; p,p'-DDT: ortho, para- dichlorodiphenyltrichloroethane; $\mathbf{\Sigma}-\mathbf{D D T}$ : sum of dichlorodiphenyltrichloroethane.

$1.081 \mu \mathrm{g} \cdot \mathrm{g}^{-1}$. It is higher than reported by Ashnagar et al., 2009, John et al., 2001, Aman and Bluthgen, 1997. The presence of lindane in all the samples might be because of the fact that $\gamma-\mathrm{HCH}$ is more resistant to biological and chemical degradation under aerobic conditions [51] and it is also most commonly used. The presence of lindane above its Maximum Residual Limit in about $50 \%$ of the samples is a cause of serious concern. It is essentially a nutritional food for infants and the aged. As it is carcinogenic in nature, it may affect the functioning of vital organs of the body [52]. It is also detected in $85 \%$ and $76.5 \%$ of the samples of fresh and pasteurized cow's milk, respectively [21]. The $\beta$-isomer of $\mathrm{HCH}$ is environmentally the most persistent among $\mathrm{HCH}$ isomers. It is eliminated slowly from the human body than lindane. It is because of this reason that this pesticide is detected in $40 \%$ samples only [53]. It has a longer half life in fatty components [54]. Most of the milk samples contained $\alpha-\mathrm{HCH}$ residues but their concentration was less. Lower concentration of $\alpha-\mathrm{HCH}$ isomer in the samples can be explained by the fact that this isomer is highly volatile and less persistent [55]. There are few places in Delhi where the concentration of $\mathrm{HCH}$ is very high as shown in Figure 4.

Dichlorodiphenyltrichloroethane (DDT) is a potent nonsystemic insecticide. Although the use of DDT has been banned in agriculture since 1993 but it is still in use for the National Malaria Eradication Program (NMEP) of Govt. of India. It could therefore be the reason of the presence of DDT and its analogues in the environment. p,p'-DDT was detected in $70 \%$ of the samples at mean levels of $0.01565 \mu \mathrm{g} \cdot \mathrm{g}^{-1}$ similar readings are also reported [56]. A major metabolite of DDT namely 2,2-bis ( $p$-chlorophenyl)-1,1-dichloroethylene (p,p'-DDE) was detected at mean levels of $0.0996 \mu \mathrm{g} \cdot \mathrm{g}^{-1}$ in the range of n.d $-0.97 \mu \mathrm{g} \cdot \mathrm{g}^{-1}$ in $80 \%$ of the milk samples of different parts of Delhi state which is higher in comparison with Waliszewski et al., 1996 [57]. DDE is more persistent than DDT. 2,2-bis(p-chlorophenyl)-1,1-dichloroethane (DDD) another metabolite of p,p'-DDT was detected at 
Table 5. Quantitative determination of $\Sigma$-Endosulfan in the milk samples collected from different regions of Delhi, India.

\begin{tabular}{|c|c|c|c|c|c|c|}
\hline $\begin{array}{l}\text { S. } \\
\text { No. }\end{array}$ & $\begin{array}{l}\text { Sample } \\
\text { ID }\end{array}$ & District & $\mathbf{A}$ & B & C & D \\
\hline 1 & S-1 & South & 0 & 0.003 & 0 & 0.003 \\
\hline 2 & S-2 & South & 0.002 & 0.0013 & 0 & 0.0033 \\
\hline 3 & S-3 & South & 0 & 0 & 0 & 0 \\
\hline 4 & SW-1 & South West & 0 & 0 & 0 & 0 \\
\hline 5 & SW-2 & South West & 0.005 & 0 & 0.0017 & 0.0067 \\
\hline 6 & SW-3 & South West & 0 & 0 & 0 & 0 \\
\hline 7 & W-1 & West & 0 & 0 & 0 & 0 \\
\hline 8 & $\mathrm{~W}-2$ & West & 0.021 & 0.022 & 0 & 0.043 \\
\hline 9 & W-3 & West & 0 & 0.022 & 0 & 0.022 \\
\hline 10 & E-1 & East & 0 & 0 & 0 & 0 \\
\hline 11 & E-2 & East & 0.006 & 0.014 & 0 & 0.02 \\
\hline 12 & $\mathrm{~N}-1$ & North & 0 & 0 & 0 & 0 \\
\hline 13 & $\mathrm{~N}-2$ & North & 0 & 0.001 & 0.0019 & 0.0029 \\
\hline 14 & NE-1 & North East & 0.002 & 0.004 & 0 & 0.006 \\
\hline 15 & NE-2 & North East & 0 & 0 & 0 & 0 \\
\hline 16 & CD-1 & Central Delhi & 0 & 0 & 0 & 0 \\
\hline 17 & CD-2 & Central Delhi & 0.001 & 0.015 & 0.002 & 0.018 \\
\hline 18 & NW-1 & North West & 0 & 0 & 0 & 0 \\
\hline 19 & NW-2 & North West & 0 & 0 & 0 & 0 \\
\hline \multirow[t]{5}{*}{20} & NW-3 & North West & 0.004 & 0 & 0 & 0.004 \\
\hline & Average & & 0.00205 & 0.004115 & 0.00028 & 0.006445 \\
\hline & Maximum & & 0.021 & 0.022 & 0.002 & 0.043 \\
\hline & Minimum & & 0 & 0 & 0 & 0 \\
\hline & Mean & & 0.00205 & 0.004115 & 0.00028 & 0.006445 \\
\hline
\end{tabular}

A: $\alpha$-Endosulfan, B: $\beta$-Endosulfan, C: Endosulfan Sulfate, D: $\Sigma$-Endosulfan.

mean levels 0.0383 in $65 \%$ of the milk samples, the concentration is lower than reported by Ashnagar et al., 2009 [56] and Kampire et al., 2011 [10]. The mean concentrations of o,p'-DDT was observed as $0.013 \mu \mathrm{g} \cdot \mathrm{g}^{-1}$ in the buffalo's milk samples of the studied area which is less as reported by Ashnagar et al., 2009 [56]. Kannan et al (1992) evaluated milk from india and found levels of DDT as $0.110 \mathrm{mg} / \mathrm{kg}$ which was above those found in the present study [58].

Total DDT (sum of pp'-DDE + pp'-DDD + op'-DDT + pp'-DDT) was detected in $85 \%$ of samples collected. Since DDT is known to undergo metabolic conversion

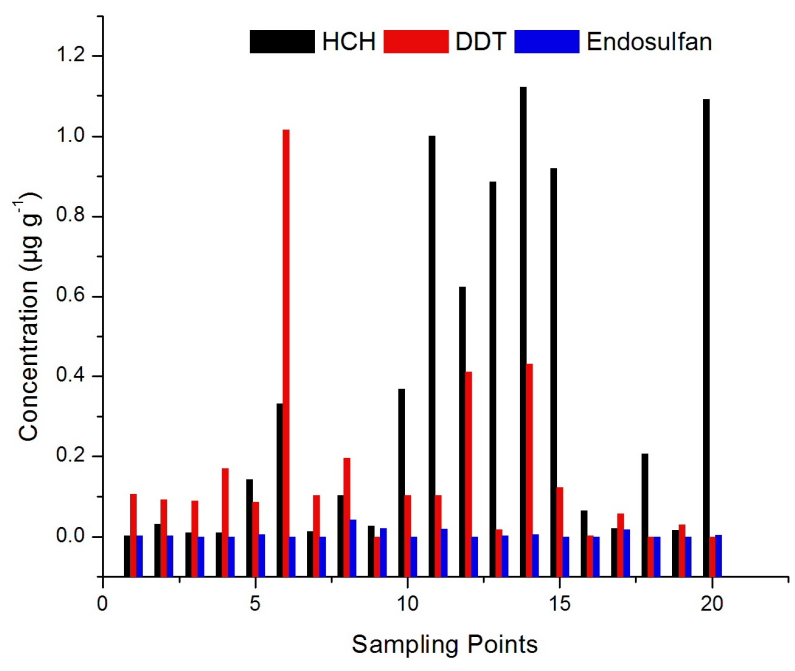

Figure 4. Residues of total Organochlorine in Milk Samples of Delhi.

and dehydrochlorination presence of metabolites of DDT i.e. DDD and DDE encountered in this study might be due to such metabolic processes. This analysis indicates that DDT is the major contaminants in different parts of Delhi state.

Endosulfan, an organochlorine insecticide of the cyclodiene subgroup acts as a poison to a wide variety of insects and mites on contact and as a stomach acaricide. Technical grade endosulfan contains $94 \% \alpha$ and $\beta$ endosulfan. The Alpha $(\alpha)$ and beta $(\beta)$ isomers are present in the ratio of $7: 3$ respectively. Alpha $(\alpha)$ isomer has been shown to be 3 times more toxic than the beta $(\beta)$ isomer. In other study, bovine milk was analysed in India to determine OC pesticides [59]. Mean levels was 0.0065, 0.0229 and $0.0198 \mathrm{mg} \cdot \mathrm{kg}^{-1}$ with $\alpha$-Endosulfan, $\beta$-Endosulfan and Endosulfan Sulfate respectively. Those values are higher than that detected in the present study. As shown in Table 5, $\alpha$ and $\beta$ Endosulfan were detected in $35 \%$ and $40 \%$ of the samples analyzed with 0.0020 and $0.0041 \mu \mathrm{g} \cdot \mathrm{g}^{-1}$ respectively. Endosulfan Sulfate a reaction product found in technical grade Endosulfan as a result of oxidation is considered to be equally toxic and more persistent than the parent compound. However it was not detected in any of the samples. Thus $\Sigma$-Endosulfan ranged from ND to $0.043 \mu \mathrm{g} \cdot \mathrm{g}^{-1}$.

\section{Conclusion}

It could be concluded that $\mathrm{OC}$ pesticide residues were detected in buffalo's milk as they were persistent in nature due to their slow decomposition rate, long half-life and high stability in the environment. In most cases, the values of detected OC pesticides were exceeded the tolerance levels of $\mathrm{FAO} / \mathrm{WHO}$. HCHs are the main contributors to the total OCs burden in milk, suggesting recent usage of HCHs in Delhi. DDT was detected in al- 
most all buffalos milk samples collected from different regions of Delhi City which were found contaminated with the presence of one or more of the investigated pesticides. Although $\alpha$ Endosulfan was detected in less analyzed milk samples than $\beta$ Endosulfan, it was 3 times more toxic. Endosulfan sulfate is not detected. Nevertheless, the organochlorine residues monitoring studies in milk as well as in cattle feed and storage condition should be investigated further in order to improve food safety since these compounds represent a potential risk to human health.

\section{REFERENCES}

[1] K. Ikhtiar and Z. Alam, "Nutritional Composition of Pakistani Wheat Varieties," Journal of Zhejiang University Science B, Vol. 8, No. 8, 2007, pp. 555-559. doi:10.1631/jzus.2007.B0555

[2] M. S. Baloch, I. U. Awan and G. Hassan, "Growth and Yield of Rice as Affected by Transplanting Dates and Seedlings per Hill under High Temperature of Dera Ismail Khan, Pakistan," Journal of Zhejiang University Science B, Vol. 7, No. 7, 2006, pp. 572-579. doi:10.1631/jzus.2006.B0572

[3] S. Rahman, N. Khalid, J. H. Zaidi, S. Ahmad and M. Z. Iqbal, "Non-Occupational Lead Exposure and Hypertension in Pakistani Adults," Journal of Zhejiang University Science B, Vol. 7, No. 9, 2006, pp. 732-737. doi:10.1631/jzus.2006.B0732

[4] N. Ribas-Fito, E. Cardo, M. Sala, M. E. de Muga, C. Mazon, A. Verdu, M. Kogevinas, O. J. Grimalt and J. Sunyer, "Breastfeeding, Exposure to Organochlorine Compounds and Neurodevelopment in Infants," Pediatrics, Vol. 111, No. 5, 2003, pp. 580-585. doi:10.1542/peds.111.5.e580

[5] M. A. Dalvie, J. E. Myers, M. L. Thompson, T. G. Robins, S. Dyer, J. Riebow, J. Molekwa, M. Jeebhay, R. Millar and P. Kruger, "The Long-Term Effects of DDT Exposure on Semen, Fertility, and Sexual Function of Malaria Vectorcontrol Workers in Limpopo Province," South African Environmental Research, Vol. 96, No. 1, 2004, pp. 1-8. doi:10.1016/j.envres.2003.09.002

[6] M. P. Longnecker, M. A. Klebanoff, H. Zhou and J. W. Brock, "Association between Maternal Serum Concentration of the DDT Metabolite DDE and Preterm and Smallfor-Gestational-Age Babies at Birth," The Lancet, Vol. 358, No. 9276, 2001, pp. 110-114. doi:10.1016/S0140-6736(01)05329-6

[7] G. S. Cooper, S. A. Martin, M. P. Longnecker, D. P. Sandler and D. R. Germolec, "Associations between Plasma DDE Levels and Immunologic Measures in AfricanAmerican Farmers in North Carolina," Environmental Health Perspectives, Vol. 112, No. 10, 2004, pp. 10801084. doi:10.1289/ehp. 6892

[8] P. J. John, N. Bakore and P. Bhatnagar, "Assessment of Organochlorine Pesticide Residue Levels in Dairy Milk and Buffalo Milk from Jaipur City, Rajasthan, India," Environment International, Vol. 26, 2001, pp. 231-236. doi:10.1016/S0160-4120(00)00111-2
[9] J. F. Davies, V. H. Freed and F. W. Whittemore, "An Agro Medical Approach to Pesticide Management," University of Miami School of Medicine, Coral Gables, 1986.

[10] E. Kampire, B. T. Kiremire, S. A. Nyanzi and M. Kishimba, "Organochlorine Pesticide in Fresh and Pasteurized Cow's Milk from Kampala Markets," Chemosphere, Vol. 84, No. 7, 2011, pp. 923-927. doi:10.1016/j.chemosphere.2011.06.011

[11] A. C. Ribeiro and S. D. A. Ribeiro, "Specialty Products Made from Goat Milk," Small Ruminant Research, Vol. 89,2010 , pp. 225-233. doi:10.1016/j.smallrumres.2009.12.048

[12] A. Alle, A. Dembelle, B. Yao and G. Ado, "Distribution of Organochlorine Pesticides in Human Breast Milk and Adipose Tissue from Two Locations in Cote d'Ivoire," Asian Journal of Applied Sciences, Vol. 2, No. 5, 2009, pp. 456-462. doi:10.3923/ajaps.2009.456.463

[13] K. Borga, G. W. Gabrielsen and J. U. Skaare, "Biomagnification of Organochlorines along a Barents Sea Food Chain," Environmental Pollution, Vol. 113, No. 2, 2001, pp. 187-198. doi:10.1016/S0269-7491(00)00171-8

[14] A. Di Muccio, I. Camoni, R. Dommarco, A. Santilio, A. Ausili, M. Rizzica, B. Gigli and C. Calzolari, "Evaluation of p,p'-DDE, p,p'-DDT and Polychlorobiphenyls (PCBs) Levels in Samples of Human Milk from Rome, Florence and the Surrounding Areas," Annali dell'Istituto Superiore di Sanita, Vol. 26, No. 2, 1990, pp. 155-160.

[15] H. Tian, "Determination of Chloramphenicol, Enrofloxacin and 29 Pesticides Residues in Bovine Milk by Liquid Chromatography-Tandem Mass Spectrometry," Chemosphere, Vol. 83, 2011, pp. 349-355. doi:10.1016/j.chemosphere.2010.12.016

[16] K. Mishra and R. C. Sharma, "Assessment of Organochlorine Pesticides in Human Milk and Risk Exposure to Infants from North-East India," Science of the Total Environment, Vol. 409, 2011, pp. 4939-4949. doi:10.1016/j.scitotenv.2011.07.038

[17] H. Van den Berg, R. Velayudhan, A. Ebol, B. H. Catbagan, R. Turingan, M. Tuso and J. Hii, "Operational Efficiency and Sustainability of Vector Control of Malaria and Dengue: Descriptive Case Studies from the Philippines," Malaria Journal, Vol. 11, 2012, pp. 269-279. doi:10.1186/1475-2875-11-269

[18] G. R. J. Khaniki, "Chemical Contaminants in Milk and Public Health Concerns: A Review," International Journal of Dairy Science, Vol. 2, No. 2, 2007, pp. 104-115. doi:10.3923/ijds.2007.104.115

[19] E. Tsiplakou, C. J. Anagnostopoulos, K. Liapis, S. A. Haroutounian and G. Zervas, "Pesticides Residues in Milks and Feedstuff of Farm Animals Drawn from Greece," Chemosphere, Vol. 80, No. 5, 2010, pp. 504-512. doi:10.1016/j.chemosphere.2010.04.069

[20] FAO/WHO, "Joint FAO/WHO Food Standards Programme-Codex Alimentarius Commission-Codex AlimentariusVolume II. Pesticide Residues in Food," Food and Agriculture Organization/World Health Organization, Rome, 1993.

[21] European Community, "Council Directive 93/57/EEC of 
29 June 1993 Ammending the Annexes to Directives 86/362/EEC and 86/363/EEC on the Fixing of Maximum Levels for Pesticides Residues in and on Cereals and Foodstuffs of Animal Origin, Respectively," Official Journal of the European Communities, Vol. 211, 1993, pp. 1-5.

[22] E. Nanu, C. Latha, B. Sunil, Prejit, M. Thomas and K. V. Menon, "Quality Assurance and Public Health Safety of Raw Milk at the Production Point," American Journal of Food Technology, Vol. 2, No. 3, 2007, pp. 145-152. doi:10.3923/ajft.2007.145.152

[23] M. Fernandez-Alvarez, M. Llompart, J. P. Lamas, M. Lores, C. Garcia-Jares, R. Cela and T. Dagnac, "Development of a Solid-Phase Microextraction Gas Chromatography with Microelectron-Capture Detection Method for a Multiresidue Analysis of Pesticides in Bovine Milk," Analytica Chimica Acta, Vol. 617, 2008, pp. 37-50. doi:10.1016/j.aca.2008.01.021

[24] S. M. Waliszewski, V. T. Pardio, K. N. Waliszewski, J. N. Chantiri, A. A. Aguirre, R. M. Infanzon and J. Rivera, "Organochlorine Pesticide Residues in Cow's Milk and Butter in Mexico," Science of the Total Environment, Vol. 208, No. 1-2, 1997, pp. 127-132. doi:10.1016/S0048-9697(97)00270-2

[25] R. K. Mishra, R. B. Dominguez, S. Bhand, R. Munoz and J. L. Marty, "A Novel Automated Flow-Based Biosensor for the Determination of Organophosphate Pesticides in Milk," Biosensors and Bioelectronics, Vol. 32, No. 1, 2012, pp. 56-61. doi:10.1016/j.bios.2011.11.028

[26] R. D. Johnson and D. D. Manske, "Pesticides in Food and Feed. Pesticide and Other Chemical Residues in Total Diet Samples," Pesticides Monitoring Journal, Vol. 11, 1977, pp. 116-131.

[27] D. Mukherjee, B. R. Roy, J. Chakraborty and B. N. Ghosh, "Pesticide Residues Inhuman Food in Calcutta," Indian Journal of Medical Research, Vol. 72, 1980, pp. 577-582.

[28] K. Fytianos, G. Vasilikiotis, L. Weil, E. Kavlendis and N. Laskaridis, "Preliminary Study of Organochlorine Compounds in Milk Products, Human Milk and Vegetables," Bulletin of Environmental Contamination and Toxicology, Vol. 34, No. 1, 1985, pp. 504-508. doi:10.1007/BF01609767

[29] P. K. Vaidya, K. C. Goyal and V. Singh, "Evaluation of Endosulfan Residue in Okra (Abelmaschus esculantus) Fruit," Ad. Bios., Vol. 10, 1991, pp. 107-110.

[30] R. Kashyap, L. R. Iyer and M. M. Singh, "Evaluation of Daily Dietary Intake of Dichlorodiphenyltrichloroethane (DDT) and Benzene Hexachloride (BHC) in India," $A r$ chives of Environmental Health, Vol. 49, 1994, pp. 63-66. doi:10.1080/00039896.1994.9934417

[31] R. S. Battu, B. Singh, K. K. Chahal and R. L. Kalra, "Contamination of Animal Feed with Residues of $\mathrm{HCH}$ and DDT," Pest Research Journal, Vol. 8, 1996, pp. 172-175.

[32] N. G. Mitra, A. Upadhyaya, B. Sachidanand and G. D. Agrawal, "Contamination of Pesticides in Samples of Milk and Milk Products," Pestology, Vol. 23, No. 8, 1999, pp. 36-40.

[33] G. Devanathan, A. Subramanian, M. Someya, A. Sudaryanto, T. Isobe, S. Takahashi, P. Chakraborty and S. Ta- nabe, "Persistent Organochlorines in Human Breast Milk from Major Metropolitan Cities in India," Environmental Pollution, Vol. 157, No. 1, 2009, pp. 148-154. doi:10.1016/i.envpol.2008.07.011

[34] R. S. Battu, B. Singh and B. K. Kang, "Contamination of Liquid Milk and Butter with Pesticide Residues in the Ludhiana District of Punjab State, India," Ecotoxicology and Environmental Safety, Vol. 59, No. 3, 2004, pp. 324331. doi:10.1016/j.ecoenv.2003.08.017

[35] R. L. Kalra and R. P. Chawla, "Studies on Pesticides Residues and Monitoring of Pesticidal Pollution," Final Technical Report, PL480 Project, Punjab, Agricultural University, Ludhiana, 1983.

[36] N. P. Agnihotri, R. S. Dewan, H. K. Jain and S. Y. Pandey, "Residues of Insecticides in Food Commodities from Delhi: II. High Fat Content Food Materials," Indian Journal of Entomology, Vol. 36, No. 3, 1974, pp. 203208.

[37] G. S. Dhaliwal and R. L. Kalra, "DDT Residues in Milk Samples from Ludhiana and Surrounding Areas," Indian Journal of Entomology, Vol. 4, No. 1, 1977, pp. 13-22.

[38] M. C. Saxena and M. K. J. Siddiqui, "Pesticide Pollution in India: Organochlorine Pesticides in Milk of Woman, Buffalo, and Goat," Journal of Dairy Science, Vol. 65, No. 3, 1982, pp. 430-434. doi:10.3168/jds.S0022-0302(82)82209-1

[39] T. S. Kathpal, G. Singh, G. S. Yadav, J. S. Dhankar and A. Singh, "Monitoring of Milk and Milk Products for DDT and HCH Contamination," Pesticide Research Journal, Vol. 4, No. 2, 1992, pp. 123-131.

[40] N. R. Kumar and A. Nath, "Monitoring of Bovine Milk for DDT and HCH," Pesticide Research Journal, Vol. 8, No. 1, 1996, pp. 90-92.

[41] U. K. Srivastava and N. T. Patel, "Pesticides Industry in India," Oxford and IBH Publishing Company Ltd., New Delhi, 1990.

[42] AOAC, "Official Methods of the Association Official Analytical Chemists," Washington DC, 1995.

[43] K. Helrich, "Official Methods of Analysis of the Association of Official Analytical Chemists," 15th Edition, Association of Official Analytical Chemists, Inc., Arlington, 1990.

[44] H. P. Their and H. Zeumer, "DFG Method S16: Organophosphorus Pesticides with Thioether Groups," In: H. P. Their and H. Zeumer, Eds., Manual of Pesticide Residue Analysis, Vol. 1, Verlag Chemie, New York, 1987, p. 309.

[45] M. C. Bowman and M. Beroza, "Determination of Fenthion and Five of Its Metabolites in Corn, Grass and Milk," Journal of Agricultural and Food Chemistry, Vol. 16, No. 3, 1968, pp. 399-402. doi:10.1021/jf60157a005

[46] V. Leoni, A. M. Caricchia and S. Chiavarini, "Multiresidue Method for Quantitation of Organophosphorus Pesticides in Vegetable and Animal Foods," Journal of Association of Official Analytical Chemists International, Vol. 75, No. 3, 1992, pp. 511-518.

[47] R. Frank, H. E. Braun, G. H. Sirons, J. Rasper and G. G. 
Ward, "Organochlorine and Organophosphorus Insecticides and Industrial Pollutants in the Milk Supplies of Ontario," Journal of Food Protection, Vol. 48, No. 6, 1985, pp. 499-504.

[48] M. P. Carvalho, M. C. Duraes, C. E. Martins, F. Deresz, J. R. F. Brito, A. F. Freitas, J. A. B. Portugal and C. N. Costa, "Effect of Nutrition on Milk Quality and Composition," Proceedings of the Anais do 2o Minas Leite: Avancos Tecnologicos Para Oaumento da Produtividade Leiteira, Juiz de Fora, May 2000, pp. 77-82.

[49] B. H. Webb, A. H. Johnson and J. A. Alford, "Fundamentals of Dairy Chemistry," 3rd Edition, Chapman and Hall, London, 1974.

[50] M. Ayub, Q. Ahmad, M. Abbas, I. M. Qazi and I. A. Khattak, "Composition and Adulteration Analysis of Milk Samples," Sarhad Journal of Agriculture, Vol. 23, No. 4, 2007, pp. 1127-1130.

[51] I. Q. El Beit, J. V. Wheelock and D. E. Cotton, "Factors Affecting Soil Residues of Dieldrin, Endosulfan, Gamma $\mathrm{HCH}$, Dimethoate and Pyrolan," Ecotoxicology and Environmental Safety, Vol. 5, No. 2, 1981, pp. 135-160. doi:10.1016/0147-6513(81)90030-0

[52] G. Vettorazzi, "State of the Toxicological Evaluation Carried Out by the Joint FAO/WHO Expert Committee on Pesticide Residues, I, Organohalogenated Pesticides Used in Public Health and Agriculture," Residue Reviews, Vol. 56, 1975, pp. 107-134. doi:10.1007/978-1-4613-9388-7 3

[53] K. Pfeilsticker, "Pesticides in Children's Diets," Monthly Journal of Pediatrics, Vol. 121, 1973, pp. 551-553.

[54] F. W. Kutz, P. H. Wood and D. P. Bottimore, "Or- ganochlorine Pesticides and Polychlorinated Biphenyls in Human Adipose Tissue," Reviews of Environmental Contamination and Toxicology, Vol. 120, 1991, pp. 1-82. doi:10.1007/978-1-4612-3080-9 1

[55] A. Kumar, P. Dayal, G. Shukla, G. Singh and P. E. Joseph, "DDT and HCH Residue Load in Mother's Breast Milk: A Survey of Lactating Mother's from Remote Villages in Agra Region," Environment International, Vol. 32, No. 2, 2006, pp. 248-251. doi:10.1016/j.envint.2005.08.019

[56] A. Ashnagar, N. N. Gharib and F. M. Cheraghi, "Determination of Organochlorine Pesticide Residues in Cow's Milk Marketed in Ahwaz City of Iran," International Journal of pharmTech Research, Vol. 1, No. 2, 2009, pp. 247-251.

[57] S. M. Waliszewski, V. T. Pardio, K. N. Waliszewski, J. N. Chantiri, R. M. Infanzon and J. Rivera, "Detection of Some Organochlorine Pesticides in Cow's Milk," Food Additives and Contaminants, Vol. 13, No. 2, 1996, pp. 231-235. doi:10.1080/02652039609374401

[58] K. Kannan, S. Tanabe, A. Ramesh, A. Subramanian and R. Tatsukawa, "Persistent Organochlorine Residues in Foodstuffs from India and Their Implications on Human Dietary Exposure," Journal of Agricultural and Food Chemistry, Vol. 40, No. 3, 1992, pp. 518-524. doi:10.1021/jf00015a032

[59] S. K. Nag and M. K. Raikwar, "Organochlorine Pesticide Residues in Bovine Milk," Bulletin of Environmental Contamination and Toxicology, Vol. 80, No. 1, 2008, pp. 5-9. doi:10.1007/s00128-007-9276-6 